\title{
Influence Of Risk Management Practices On Credit Performance In Islamic Banking At First Community Bank In Nairobi, Kenya
}

\author{
Johnson Njoroge ${ }^{1}$, Solomon Ngahu ${ }^{2}$ \\ ${ }^{l}$ School of Business, Jomo Kenyatta University of Agriculture and Technology. \\ ${ }^{2}$ School of Business, Jomo Kenyatta University of Agriculture and Technology.
}

\begin{abstract}
Islamic banks face new and unique risk stemming from their unique assets and liability structure as compared to conventional banks. This new risk exists due to compliance with Sharia requirements. Therefore this study sought to establish the influence of risk management practices on credit performance of first community bank (FCB) in Nairobi Kenya. Specifically the influence of risk identification on credit performance in FCB was examined. The study utilized risk management theory. A descriptive survey research design was employed with census approach used in data collection. The target population included branch managers, operations managers, and credit officer in the seven branches of FCB in Nairobi making a total of 56 respondents. Research questionnaires were used for data collection. Data was analyzed in form of descriptive and inferential statistics. Analysis was done using Statistical Package for Social Sciences (SPSS) version 24. The study established that risk identification had significant relationships with the credit performance in FCB. It was concluded that risk identification played a key role in credit performance of the bank. The researcher recommended that the board of management should enhance risk management policies that would improve their risk management practices.
\end{abstract}

\section{Keywords: Bank, Islamic Bank, Risk Management Practices, Credit Performance and Risk Identification}

\section{INTRODUCTION}

Risk is inevitable and inborn in each and every economic activity. According to Brain (2001) risk occurs when outcome is uncertain. Risk exists as a part of an environment in which various organizations operate (Shafiq \& Nasr, 2010) so each and every business has to face risk. Without taking risk, growth of business is like a nightmare (Asim et al., 2012). Banks like all businesses face various types of risk which arise due to the nature of their activities.

The major aim of banks is to maximize profit by managing risk and by providing various financial services (Alimshan, 2011). In Practice we have two banking systems. One which follows normal interest based practices called conventional banking and second which follows Islamic law and perform interest free activities which is known as Islamic banking (Khattak et al., 2013). Both these banking systems are distinguished as conventional banks follow the Standard Operating Procedures (SOPs) prepared by their higher authority; their income is interest which is earned by lending money and they transfer the entire risk to others. While Islamic banks follow policies made by Sharia'h that prohibits interest that's why Islamic banks do not deal in interest and are trade-oriented banks, their income is profit which is earned by trading. They share risk with both lenders and borrowers (Ashfaq, 2009).

Islamic banking has become one of the vital sources of economic growth, particularly in countries where a significant number of Muslims refuse to deal with Riba transactions (Alwady \& Samhan, 2007). Although the issue of Risk Management Practices in Islamic banking institutions (IBs) has been widely debated by academics, risk management committees, practitioners, accountants, and investors, the issue continues to be of remarkable interest. Risk management experts, practitioners, academics and others, acknowledge that the presence of effective risk management departments is the cornerstone for the management of economic and financial institutions, including banks (Abu Hussain \& Al-Ajmi, 2012).

A distinctive feature of Islamic banks is the obligation to conduct operations in accordance with principles of sharia, which is the religious law of Muslims. The basic sharia principle applied by Islamic financial institutions is the prohibition of usury (arab. riba). This principle has its origins in the holy book of Muslims - Koran. The hadiths, which describe the life and actions of Muhammad, the Messenger of Allah, also state that riba is condemned. However, neither the Koran nor the hadiths define what riba is. According to most Islamic economists riba is any sort of increase over the principal amount (Hasanuz Zaman, 2001). The prohibition of riba has huge implications on operations conducted by Islamic banks since none of them can be based on interest. 
Risk management is an integrated process that seeks for specific means to control risks and reduce the frequency thereof, and reduce the size of loss using the best means and lowest cost by identifying, analyzing, and assessing risks and identifying the means to address them, by selecting the best among them to achieve the desired goal (Taher, 2004). Khan and Ahmed (2001) observe that Islamic banks do not only face the same risks that conventional banks face, but have to deal with the new and unique risk stemming from their unique assets and liability structure. According to them, this new risk exists due to compliance with Sharia requirements. Most of Islamic financial institutions' activities are based on profit and loss sharing; which indicates that such transactions pose lower risks. However, contracts based on profit and loss sharing expose Islamic financial institutions to a specific risk depending on the type of each contract.

Arunkumar and Kotreshwar (2005) revealed that credit risk constitutes $70 \%$ of the total risk in banks, while the remaining $30 \%$ is shared by market and operational risk. Khan (2003) indicates that credit risk is the most important source of banking instability and capital is widely recognized as an effective security against the insolvency of banks. Basel Committee, the international banking supervisory body also claims that the key source of critical banking problems is the credit risk, the risk of customer default. The foregoing prompts the undertaking of this study to establish the influence of risk management practices on credit performance in first community bank in Nakuru town.

\section{ISLAMIC BANKING IN KENYA}

In Kenya, Islamic banks are not separately defined in the Banking Act. All banks including those operating pursuant to Islamic Banking principles are subject to the requirements of the Banking Act. Indicators in the first year of operations of the two fully-fledged Islamic banks pointed to potential for Islamic banking in Kenya. There is still room to grow this market niche given tremendous expansion of Kenya's banking sector for instance, the number of bank accounts tripled from 2.6 million in 2005 to 7.5 million in 2009 (Gulf African Bank, 2014). Currently there are 2 fully fledged Islamic Banks and five commercial banks offering Islamic bank product and services in Kenya (CBK, 2015). Islamic Banking prohibits interest but allows profit sharing. Therefore Sharia compliant financing products have element of "trading" and "holding of fixed assets" as the bank has to buy and sell financed assets. However, Section 12 of the Banking Act restricts trading and holding of fixed assets and thus the Banking Act was amended in 2006 to enable exemption of innovative products such as Sharia compliant banking financing products from trading and holding of fixed assets restrictions.

Barclays' La Riba account was the first-ever Shariah-compliant account in Kenya. The account was set up in December 2005. However, Kenya's first Islamic bank, First Community Bank (FCB) was granted a banking license in May 2007. The bank started operations in May 2008. Apart from FCB, Gulf African Bank is the other bank in Kenya with a license to operate as a fully-fledged Islamic bank. Other banks in Kenya such as Kenya Commercial Banks, Barclays Bank, Standard Chartered Bank, Chase Bank and National Bank have Islamic windows. The study is focusing on Islamic Banking because much of the research that has been done on the effect of risk management on credit performance has been on conventional banks. Therefore, there exists knowledge gap on how risk management in Islamic Banks affects their credit performance as they employ different banking approaches from conventional banks (CBK, 2015).

\section{STATEMENT OF THE PROBLEM}

Risk is a major factor to be considered in every financial intermediation. It is a great threat to financial business and its effective management should be considered in attaining performance. Most credit decisions in financial institutions expose its management to some level of risk, hence the need for effective risk management policy. It involves identification, quantifying and managing the uncertainties that firm faces as outcomes of financial intermediation activities are uncertain which in turn result to risk. Risks come to play as a result of strategic failure, operational failure, financial failure, market failure and disruptions, environmental disaster and regulatory violations. Credit risk is a big threat for banks as the value of any organization is measured by its credit worthiness. Therefore, credit risk management is of critical importance for the good performance of banks. It is expected that good credit risk management would result to greater performance through higher profit, good productivity, increased capital investment and also create opportunities that would improve the standard of living. The banks' motivation for risk management comes from the tendency of risks leading to bank underperformance (Eduardus et al., 2007). Based on the fact that Islamic banking has numerous idiosyncratic characteristics, the temperament and extent of risk facing such organizations may be considerably different due to the concept of profit-sharing approach in Islamic banks. Furthermore, Islamic banks are constrained in using some of the risk mitigation instruments that their conventional counterparts use as these are not allowed under Islamic commercial law. There have been a fairly small number of academic studies available on Islamic banks about risk management. However, this study creates uniqueness with the extent of influence involved towards credit performance. 


\section{OBJECTIVE OF THE STUDY}

The general objective of the study was to examine the influence of risk management practices on credit performance in First community bank in Nairobi, Kenya. Specifically, the study examined the influence of risk identification on credit performance in FCB in Nairobi, Kenya. The study was guided by the following research question.

What is the influence of risk identification on credit performance in FCB in Nairobi, Kenya?

\section{RISK MANAGEMENT THEORY}

Wenk (2005), states that the Risk Management model consists of risk identification, risk assessment, and prioritization of risks followed by coordinated and economical application of resources to minimize, monitor, and control the probability and/or impact of unfortunate events or to maximize the realization of opportunities. Risks can come from uncertainty in financial markets, project failures, legal liabilities, credit risk, accidents, natural causes and disasters as well as deliberate attack from an adversary, or events of uncertain or unpredictable root-cause. Several risk management standards have been developed including the Project Management Institute, the National Institute of Science and Technology, actuarial societies, and ISO standards. Methods, definitions and goals vary widely according to whether the risk management method is in the context of project management, security, engineering, industrial processes, financial portfolios, actuarial assessments, or public health and safety (Simkins and Fraser, 2010). The strategies to manage risk typically include transferring the risk to another party, avoiding the risk, reducing the negative effect or probability of the risk, or even accepting some or all of the potential or actual consequences of a particular risk.

Effective risk management can bring far reaching benefits to all organizations, whether large or small, public or private sector (Ranong and Phuenngam, 2009). These benefits include, superior financial performance, better basis for strategy setting, improved service delivery, greater competitive advantage, less time spent fire fighting and fewer unwelcome surprises, increased likelihood of change initiative being achieved, closer internal focus on doing the right things properly, more efficient use of resources, reduced waste and fraud, and better value for money, improved innovation and better management of contingent and maintenance activities (Wenk, 2005).

\section{RISK IDENTIFICATION AND CREDIT PERFORMANCE}

Hull (2007) explains that one of the basic formation of every organization, most importantly a banker is to understand the portfolio of risk it faced currently and the risk it plans to take in future. Chapman further argued that the risk identification processes would normally be conducted solely by the risk analyst interviewing a member of IBs, or by the risk management committee. Procedures at this stage include identifying events or threats that confront IBs; estimating the likelihood of each threat; estimating the positive or negative impact resulting from each threat; identifying procedures or controls to mitigate the threats; estimating the cost and benefit from implementing controls; and deciding whether to avoid, share, accept, or transfer the risks (Romney \& Steinbart, 2012). Abdul Rahman et al. (2012) examined the risk management practices of Islamic Banks in Malaysia and Indonesia and discovered that IBs in Malaysia are using more sophisticated quantitative analysis methods at this stage compared to IBs in Indonesia.

Risk identification is positively significant to influence risk management practices. In the case of banks, studies made especially on risk identification and risk mitigation includes the work of Haron and Hin Hock (2007) on market and credit risk, and Haron (2007) specifically on operational risk. Haron and Hin Hock (2007) explain the inherent risk; credit and market risk exposures in Banks. Also, they illustrate the notion of displaced commercial risk that is important in Banks. They conclude that certain risks may be considered as being inherent in the operations of conventional banks. Although the risk exposures of Banks differ and may be complex than conventional financial institution, the principles of credit and market risk management are applicable to both. In addition, the IFSB's standards on capital adequacy and risk management guiding principles mark the first steps in an ongoing process of developing prudential standards and filling regulatory gaps in the field of finance.

In (2002), Al-Tamimi, discovered that the UAE commercial banks faced credit risks. The study also discovered that follow-up and inspections by branch managers and financial statement analysis were the main methods used in risk identification (are the following; establishing standards, credit scores, credit worthiness analysis, risk rating and collateral) among the techniques used in risk management. Dan (2011) aimed to outlines strategies to identify, prioritize, and mitigate risks for the achievement of projects' or organizational objectives and in order to fulfill performance and profitability needs. Risk management helps projects and organizations and at the same time prevents the loss of resources. It provides potentially profitable returns on investments for the organizational management, project management, project stakeholders, and team members. Here help is given as an entity get to where it wants to go and avoid unforeseen circumstances along the way. 


\section{CREDIT PERFORMANCE}

Jamali, Shar and Ali (2012) assert that bank performance is a very important subject to all the banks' stakeholders including customers, investors and the general public. Consequently, numerous studies have been undertaken on financial institutions to determine their impact on the efficiency of economic growth and also discover the determinants of successful bank performance. There are various techniques and financial performance indicators used by researchers to evaluate the determinants of successful bank performance, including internal bank-specific factors (such as liquidity and asset quality) and external macroeconomic variables (such as GDP growth rate and annual inflation).

Felix and Claudine (2008) investigated the relationship between bank performance and credit risk management. It could be inferred from their findings that return on equity (ROE) and return on assets (ROA) both measuring profitability were inversely related to the ratio of non-performing loan to total loan of financial institutions thereby leading to a decline in profitability.

Al-Tiby (2012) asserts that IBs face another crucial challenge in improving their risk management strategies and corporate governance because of their adherence to Sharia'a principles. They are currently exposed to all types of risk including those faced by CBs and those unique to IBs. Ikha and Abdullah (2011) declare that the assets and liability structures of IBs have unique risk characteristics as a result of the Islamic banking model evolving into pure Islamic modes and instruments as previously discussed. Rehman et al (2011) and Merchant (2012) further elaborate that "on the liability side of Islamic banks, saving and investment deposits take the form of profit sharing investment accounts and demand deposits take the nature of qard hasan (interest-free loans) that are returned fully on demand.

While on the asset side, banks use murabaha, bai-muajjal, istisnaa, salam and ijara and PLS modes of financing (musharaka and mudaraba). These instruments on the asset side, using the profit-sharing principle to reward depositors, are a unique feature of Islamic banks". Hence, while the conventional banks guarantee the capital and rate of return, the Islamic banking system, based on the principle of PLS, cannot, by definition, guarantee any fixed rate of return on deposits. In some cases the capital is not guaranteed either, because if there is a loss it has to be deducted from the capital. As a result, Hassan (2009) confirms that IBs face not only the regular risks encountered by conventional banks but they also face other risks as a result of their unique asset classes and liability structures.

Manarvi \& Muhammad (2011) and Momeneen \& Jaffar (2011) compared the performance of the Islamic and the conventional banks in Pakistan using the CAMEL test. They both concluded that the Islamic banks are better in processing adequate capital and present a better liquidity position of IBs as compared to CBs in Pakistan, however CBs pioneered in management quality and earning ability, while asset quality for both streams of banking was almost the same. These findings are also consistent with the results of Ika and Abdullah (2011) that concluded that IBs in Indonesia are more liquid than CBs and have better liquidity management practices.

Kithinji (2010) assessed the effect of credit risk management on the profitability of commercial banks in Kenya. Data on the amount of credit, level of non-performing loans and profits were collected for the period 2004 to 2008. The findings revealed that the bulk of the profits of commercial banks are not influenced by the amount of credit and non-performing loans, therefore suggesting that other variables other than credit and nonperforming loans impact on profits.

In a study by Javaid, Anwar and Zaman (2011) to discover the main determinants of the profitability of banks in Pakistan using internal factors only (the impact of assets, loans, equity, and deposits on profitability). The empirical results showed that these variables have a strong influence on the profitability. However, they concluded that higher total assets may not necessarily lead to higher profits due to diseconomies of scales and that higher loans contribute towards higher profitability however their impact is not significant. Respectively, Ali, Akhtar and Ahmed (2012), also studied the determinants of profitability of banks in Pakistan however using both internal and macroeconomic variables. The study documented a significant effect of capital adequacy ratio, credit risk, asset management, GDP and consumer price index with profitability when measure with return on assets (ROA) and significant relation of operating efficiency, asset management and GDP with profitability when measured with return on equity (ROE).

\section{RESEARCH METHODOLOGY}

The study employed a descriptive survey research design. According to Burns \& Grove (2003), the purpose of research design is to achieve greater control of the study and to improve the validity of the study by examining the research problem. The target population of the study included the branch managers, operations managers, credit managers and the five credit officers in each of the seven branches of the first community bank in Nairobi. Based on the small size of the population, the researcher opted to adopt a census survey where all the elements in the target population were considered as the study respondents. The study used structured questionnaires that were distributed to the employees of FCB in Nairobi. The questionnaires contained a five 
point Likert scale (5-strongly agree, 4-agree, 3-neutral, 2-disagree and 1-strongly disagree) to measure risk management strategies and credit performance. Data collected was processed and analyzed based on the objectives and research hypotheses using Statistical Package for Social Sciences (SPSS) version 21. This was done using both descriptive and inferential statistics. Descriptive statistics (percentages, frequencies, and means) presented in tables was used to organize and summarize data and to describe the characteristics of the sample while Pearson correlation coefficient was used to check the relationship between variables.

\section{FINDINGS AND ANALYSIS}

The researcher distributed 50 questionnaires to be filled by the respondents of which 44 of them were completely filled and returned. This represented a response rate of $88 \%$ which was characterized as very good. Descriptive statistics on risk identification gave the following results.

\begin{tabular}{|l|c|c|}
\hline \multicolumn{3}{|c|}{ Table 1: Respondents views on Risk Identification } \\
\hline
\end{tabular}

Table 1 showed that all the responses had means approximately equal to 4 meaning that they agreed with all the issues relating to risk identifications. Further, the responses recorded small range values showing that their opinions were dispersed from one another a fact attested also by small standard deviations. The respondents agreed that in the process of identifying risk, the bank always puts sharia compliance issues into consideration and that the bank has a risk management committee tasked with risk identification. On the other hand respondents agreed that the bank frequently performs risk survey to identify potential risks and that changes in risk are recognized and identified with the Islamic Bank's rules and responsibilities. Additionally, respondents agreed that risk identification is purely based on quantitative analysis methods and that the bank uses financial statement analysis method for risk identification.

On the other hand, descriptive statistics on credit performance gave the results showed in Table 2 below.

\begin{tabular}{|c|c|c|c|c|}
\hline \multicolumn{5}{|c|}{ Table 2: Views on Credit Performance } \\
\hline & $\mathrm{N}$ & Range & Mean & $\begin{array}{l}\text { Std. } \\
\text { Dev }\end{array}$ \\
\hline $\begin{array}{l}\text { The bank has drastically reduced non-performing loans due to proper risk } \\
\text { management }\end{array}$ & 44 & 3 & 4.02 & .762 \\
\hline Our credit manual is always up to date and convenient for loan creation & 44 & 3 & 4.02 & .821 \\
\hline Our credit policy has been made flexible for the benefit of our clients & 44 & 3 & 3.98 & .849 \\
\hline The bank has observed improved growth in loan uptake & 44 & 3 & 3.95 & .806 \\
\hline The bank has in most cases had to write off the non-performing loans & 44 & 3 & 3.95 & .714 \\
\hline Most of our clients are satisfied with our loan processing procedures & 44 & 3 & 3.95 & .714 \\
\hline Valid N (list wise) & 44 & & & \\
\hline
\end{tabular}

Respondents were in agreement that the bank has drastically reduced non-performing loans due to proper risk management $(\mathrm{M}=4.02)$ and that their credit manual is always up to date and convenient for loan creation $(M=4.02)$. They also agreed $(M=3.98)$ that their credit policy has been made flexible for the benefit of their clients and that the bank has observed improved growth in loan uptake $(M=3.95)$. In addition, they also agreed $(M=3.95)$ that the bank has in most cases had to write off the non-performing loans and that most of their clients are satisfied with their loan processing procedures $(M=3.95)$. All responses had range value of 3 and standard deviation values less than one. This indicated that the respondents did not give diverse opinions but closely related views.

The relationship between risk identification and credit performance was established as shown in Table 3 below.

Table 3: Correlations 
Influence Of Risk Management Practices On Credit Performance In Islamic Banking At First

\begin{tabular}{|c|c|c|c|}
\hline & & Risk Identification & Credit Performance \\
\hline \multirow[t]{3}{*}{ Risk Identification } & Pearson Correlation & 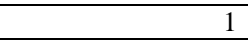 & $.334^{*}$ \\
\hline & Sig. (2-tailed) & & .027 \\
\hline & $\mathrm{N}$ & 44 & 44 \\
\hline \multirow[t]{3}{*}{ Credit Performance } & Pearson Correlation & $.334^{*}$ & 1 \\
\hline & Sig. (2-tailed) & .027 & \\
\hline & $\mathrm{N}$ & 44 & 44 \\
\hline
\end{tabular}

The study established the presence of a weak positive significant relationship between risk identification and credit performance. The relationship was significant at $\mathrm{p}<.05$ level of significance. Thus there is a direct linear relationship between risk identification and credit performance in FCB. Therefore the researcher concluded that risk identification has a significant influence on credit performance.

$\mathbf{X}$ CONCLUSIONS AND RECOMMENDATIONS OF THE STUDY

The findings indicated that FCB had frequent conduction of risk surveys to identify potential risks and formulating measures to curb the potential risks. The researcher therefore noted that frequent processes for risk identification are a pre-requisite for credit performance. The study recommended that the board of management should enhance risk management policies that would improve their risk management practices. Thus the study recommends that the institution should enhance their risk identification methods as they were shown to significantly influence credit performance. Procedures for risk identification need to be improved in order to enhance the efficiency in risk identification.

\section{REFERENCES}

[1] Shafiq, A. \& Nasr, M. (2010). "Risk Management Practices Followed by the Commercial Banks in Pakistan." International Review of Business Research Papers, 6(2), 308-325.

[2] Khattak, N., Khashif-ur-Rehman, Majeedullah \& Wasimullah (2013). Risk management practices and attitude of Pakistani Islamic banking system employees.African Journal of Business Management, Vol. 7(33), pp. 3202-3210.

[3] Al Wadi, M. H., \& Samhan, H. M. (2007). Islamic banks - the theoretical basis and applications (1st ed.). Dar Almasira, Amman, Jordan.

[4] Abu Hussain, H, \& Al-Ajmi, J. (2012). Risk Management Practices of Conventional and Islamic Banks in Bahrain. The Journal of Risk Finance, 13(3).

[5] Hasanuz Z. (2001). Conceptual Foundations of Riba in Qur'an, Hadith and Fiqh, “Journal of Islamic Banking and Finance”, 18, 34.

[6] Taher, M. (2004). Modern Risk Management in Banking and Finance. Beirut: Union of Arab Banks.

[7] Khan, T. \& Ahmed, H. (2001). Risk Management: An Analysis of Issues in Islamic Financial Industry, Occasional Paper No. 5, Islamic Research and Training Institute, Islamic Development Bank. Jeddah -Saudi Arabia.:21-183.

[8] Arunkumar, R., \& Kotreshwar, G. (2005). Risk Management in Commercial Banks (A Case Study of Public and Private Sector Banks). SSRN eLibrary.

[9] Khan, T. (2003). Credit risk management: A framework for Islamic banking. Islamic banking: risk management, regulation and supervision, Jakarta, Indonesia.

[10] Wenk, D. (2005). "Risk Management and Business Continuity, Overview and Perspective". Journal of the Chartered Insurance Institute. 3(3), pg. 234-246

[11] Hull, J. (2007). Risk Management and Financial Institutions, Pearson Prentice Hall, New Jersey, pp. 1-10.

[12] Romney, M. B., \& Steinbart, P. J. (2012). Accounting information systems. England: Pearson-Prentice Hall.

[13] Abdul, A., Khan, A. \& Nazir, N. (2012).A comparative study of credit risk management: a Case study of domestic and foreign banks in Pakistan. Academic Research International, Vol. 3, pp. 371-377.

[14] Haron, A. \& Hin Hock, J. (2007). "Inherent Risk: Credit and Market Risks" in Archer, S. and Karim, R. A. A. 2007, "Finance: The Regulatory Challenge", John Wiley \& Son (Asia) Pte Ltd.

[15] Dan B., (2011)," On Best Practices for Risk Management in Complex Projects”, Informatica Economică vol. 15, no. 2/2011.

[16] Felix, A. \& Claudine, T. (2008). Bank Performance and Credit Risk Management, Unpublished Masters Dissertation in Finance, University of Skovde.

[17] Ikha, S., \& Abdullah, N. (2011). A comparative study of Financial performance of Islamic banks and conventional banks in Indonesia. International Journal of business and Social sciences. Retrieved from Emerald Database.

[18] Merchant, I. (2012). Empirical Study of Islamic Banks Versus Conventional Banks of GCC. Global Journal of Management and Business Research, 12 (20).

[19] Javaid, S. Anwar, J., Zaman,K. \& Gafoor, A. (2011). Determinants of Bank Profitability in Pakistan: Internal Factor Analysis. Mediterranean journal of social sciences, 2, (1). ISSN 2039-2117

[20] Ali, K., Akhtar, M. F., \& Ahmed, H. Z. (2012). Bank-Specific and Macroeconomic Indicators of Profitability - Empirical Evidence from the Commercial Banks of Pakistan. International Journal of Business and Social Science, 2(6), 235-242

[21] Burns, N. \& Grove, S. (2003). Understanding nursing research. (3 ${ }^{\text {rd }}$ Ed.). Philadelphia. PA: W S Saunders. 